\title{
Chemical composition of the muscle tissue of ray (Raja radiata) from Terranova
}

\author{
L. Pastoriza \& G. Sampedro
}

Instituto de lnvestigaciones Marinas, Eduardo Cabello, 6, 36208 Vigo, Spain

The proximate analysis, nitrogen compound content and lipid and fatty acid analysis of the muscle of frozen ray (Raja radiata) caught in Terranova have been studied.

The proximate analyses of the muscle were: $15 \%$ real protein, $1 \%$ non-protein nitrogen, $78 \%$ humidity and a fatty acid content lower than $1 \%$. The urea reaches values of $2 \%$. In the lipid fraction 14 fatty acids were identified. Palmitic acid (16:0) and stearic acid (18:0) were the majority fatty acids and represent $61.55 \%$ and $33-86 \%$, of the total saturated fatty acids. Oleic acid (18:1) was the most abundant of the monounsaturated fatty acids and corresponds to $72.72 \%$ of the total of these. Arachidonie acid (20:4), eicosapentaenoic acid (20:5) and docosahexaenoic acid (22:6) were the most predominant polyunsaturated acids, forming $12.95,57.22$ and $23.67 \%$ of the total of polyunsaturated fatty acids respectively. The results show that the lipid fraction of the ray (Raja radiata) is an excellent source of polyunsaturated fatty acids with high levels of omega-3 (n-3) especially the eicosapentaenoic and docosahexaenoic acids.

\section{INTRODUCTION}

The ray, which is an abundant fish resource, is still scarcely considered from the technological and commercial point of view. Moreover, a scientific study to establish its chemical characteristics and nutritional properties has not provoked interest. This may be due to its deficient exploitation.

However, in the last decade, ray consumption has increased in Spain due to greater catches of this species by the freezing fleet in the Terranova fishing grounds.

Since then, it has been commercialised in the form of frozen ray wings. 
The ray also showed promise as a raw material for new transformation processes (Pastoriza \& Sampedro, 1991a) which brought about new finished food products. The aim of this work is to determine the nitrogen compound content (characteristic in this species) and also to study the lipid fraction of the commercialised muscular part of the fish.

In general, the bromatological research which is being carried out on the fish with respect to diet and nutrition, indicates that the sea fish contains high proportions of polyunsaturated fatty acids of the n-3 (PUFA) series and higher quantities than the fresh water fish. Because of this, special attention is given to the study of the polyunsaturated fatty acids in the ray.

The effect that the fatty acid composition has on health makes it necessary for research to be focused on the study and knowledge of these substances and on their quantitative ratio analysis.

\section{MATERIAL AND METHODS}

The ray (Raja radiata) was caught in February by the Spanish fishing fleet in the Terranova area. The fish was frozen on board immediately after being caught.

The sampling on land was carried out on the muscle of the species once it was defrosted in the refrigerator $\left(8-10^{\circ} \mathrm{C}\right)$ and the muscle tissue was homogenised in a mincer (MOBBA, 3CV).

The total nitrogen was determined using the Kjeldahl technique (1953), the protein and non-protein nitrogen according to Kjeldahl's technique after separation, by precipitation of the protein fraction with trichloroacetic acid (10\%); the urea content was determined by colorimetric reaction with the reagent p-dimethylaminobenzaldehyde according to the AOAC (1984) method.

The lipids were separated following a modification of Bligh and Dyer's (1959) method. They were first extracted with chloroform-methanol (1:2) and, after centrifuging, the sediment was again treated with chloroform-methanol (2:1) (Fernández Reiriz et al., 
1989); both supernatants were washed with chloroform-methanol-water (8:4:3) (Folch et al., 1957). The total lipids were determined by March and Weinstein's (1966) method using tripalmithine as standard.

The fatty acids were quantified by gas-liquid chromatography after transesterification. A chromatograph VARIANT VISTA 6000 equipped with a capillary column of fused silica, SP 2330, $30 \mathrm{~m}$ length, 0-25 mm i.d., 0-20 mm of standard film was used. The detector temperature was $250^{\circ} \mathrm{C}$, injected with PTV, and a temperature program:

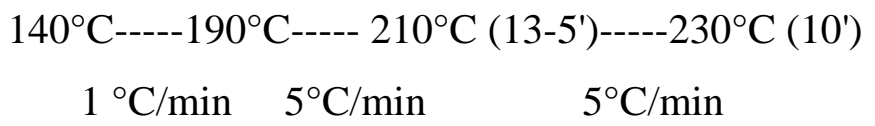

\section{RESULTS AND DISCUSSION}

The proximate analyses of the fish are shown in Table 1. In the skinned ray wing muscle there was a humidity content of $78-10 \%, 0.62 \%$ lipids, $21.02 \%$ gross protein and $15-18 \%$ real protein.

The difference which appears between the gross and real protein, seen in all elasmobranch fish, is the consequence of the high non-protein nitrogen compared with other fish species. In this study, quantities of $3.34 \%$ protein and $0.98 \%$ non-protein nitrogen have been found (Table 2). The urea content reached values of $2 \%$, a similar quantity to those found in other elasmobranch fish (Suyama \& Tokuhino, 1954; Simidu, 1961; Stansby \& Olcott, 1963).

The lipid fatty acid composition of this ray is listed in Table 3. Fourteen fatty acids were identified, the total quantity of saturated fatty acids (8.74\%) was inferior to that found for the ray (Rhinobatos granulatus) (Nair \& Gopakumar, 1977). The results show that palmitic acid (16:0) was the predominant fatty acid. Ackman and Eaton (1966) indicate that palmitic acid (16:0) was a metabolic key in the fish and that its levels were not influenced by diet.

The total of monounsaturated fatty acids was $15.18 \%$ with oleic acid (18:1) being in the majority, similar to the result of Nair and Gopakumar (1977). 
The main acids within the polyunsaturated group were arachidonic acid (20:4), eicosapentaenoic acid (20:5) and docosahexaenoic acid (22:6). The concentrations of 20:5 were higher and those of 22:6 lower than those observed in another ray species (Nair \& Gopakumar, 1977).

The n-3/n-6 ratio was calculated to establish comparative proportions between these polyunsaturated series. This ratio corresponds in the present case to a value of 4.23 ; the index is higher than those quoted for 22 species of seawater fish which were previously determined by Hearn et al. (1987) and to other species of freshwater fish (Wang et al., 1990).

Therefore, the ray studied is an interesting fish as far as its n-3 series polyunsaturated fatty acids are concerned.

On the other hand, in Spain, the exploitation of this ray, begun in 1984, has shown an increase since 1986, which has made this species a suitable raw material for technological use in the transformation industry and for the manufacture of new food products. In this study, the possibility to further revalue this fish resource is raised, increasing its utilisation and exploitation capacity. Different technological processes have recently been investigated (Pastoriza \& Sampedro, 1991a) in which ray (Raja radiata) was used as raw material and good quality commercial products were originated. These authors also emphasise the significant urea loss in the muscle of the species after undergoing thermic treatment (Pastoriza \& Sampedro, 1991b) which greatly improves its organoleptic characteristics.

In summary, the favourable judgement of the finished products given by sensorial qualification specialists, the urea reduction during the thermic treatments, along with the interesting qualities of the lipid fraction, make this species worthy of further research,

\section{ACKNOWLEDGEMENTS}

This study has been carried out with the backing of the lnterministerial Commission of Science and Technology (CICYT) in the Research Project AL189-0555. 
The authors would like to thank Dr Fernández Reiriz and D. Jos6 Luis Garrido for the fatty acid determination. Thanks also to Dña. M $^{\mathrm{a}}$ Cruz Nuñez and D. Carlos Suárez for help given.

\section{REFERENCES}

Ackman, g. G. \& Eaton, C. A. (1966). Some commercial Atlantic herring oils fatty acid composition. J. Fish. Res. Bd. Canada, 23(7), 991-1006.

AOAC (1984). Official Methods of Analysis, 14th edn. Association of Official Analytical Chemists, Arlington, VA, USA.

Bligh, E. G. \& Dyer, W. J. (1959). A rapid method of total lipid extraction and purification. Can. J. Biochem., 37, 911.

Fernandez Reiriz, M. J., Perez Camacho, A., Ferreiro, M. J., Blanco, J., Planas, M., Campos, M. J. \& Labarta, U. (1989). Biomass production and variation in the biochemical profile (total protein, carbohydrates, RNA, lipids and fatty acids) of seven species of marine microalgae. Aquaculture, 83, 17-33.

Folch, J., Lees, M. \& Sloane-Stanley, G. H. (1957). A simple method for the isolation and purification of total lipids from animal tissues. J. Biol. Chem., 226, 497.

Hearn, T. L., Sgoutas, S. A., Hearn, J. A. \& Sgoutas, D. S. (1987). Polyunsaturated fatty acids and fat in fish flesh for selecting species for health benefits. J. Food Sci., 52(5), 1209-11.

March, J. B. \& Weinstein, D. B. (1966). Simple charring method for determination of lipids. J. Lipids Research, 7, 574-6.

Nair, K. G. R. \& Gopakumar, K. (1977). Fatty acid composition of marine fish body fat. J. Food Sci. Technol., 14(6), 268-70.

Pastoriza, L. \& Sampedro, G. (1991a). Revalorizaci6n comercial de la raya (Raja radiata). Paper presented at the $3^{\text {rd }}$ World Congress of Food Technology, Barcelona, Spain, 20-23 February, Abstract p. 53.

Pastoriza, L. \& Sampedro, G. (1991b). Loss of urea from the flesh of ray (Raja radiata) during the canning process. Inter. J. Food Sci. TechnoL, 26, 211-13.

Simidu, W. (1961). Non protein nitrogenous compounds. In Fish as Food, vol. 1, ed. G. Borgstrom. Academic Press, London, pp. 353-84.

Stansby, M. \& Olcott, H. (1963). Composition of fish. In Industrial Fishery Technology, ed. M. Stansby. Reinhold Publishing Corporation, London, pp. 339-49. 
Suyama, M. \& Tokuhiro, T. (1954). Urea content and ammonia formation of the muscle of cartilagenous fishes. Bull. Japanese Soc. Sci. Fish., 19(9), 935-8.

Wang, Y. J., Miller, L. A., Perren, M. \& Addis, P. B. (1990). Omega-3 fatty acids in Lake Superior fish. J. Food Sci., 55(1), 71-3, 76. 
Table 1. Proximate analysis of the ray

\begin{tabular}{lll}
\hline & $\begin{array}{l}\text { Skinned ray } \\
\text { wings (\%) }\end{array}$ & $\begin{array}{l}\text { Waste } \\
\text { (heads, tails and guts) (\%) }\end{array}$ \\
\hline Humidity & 78.10 & 74.56 \\
Lipid & 0.62 & 2.88 \\
Gross protein $^{\mathrm{a}}$ & 21.02 & 19.44 \\
Real protein $^{\mathrm{a}}$ & 15.18 & - \\
Ash & 2.01 & 3.42 \\
\hline
\end{tabular}

${ }^{\mathrm{a} C a l c u l a t e d}$ as ( $\mathrm{N} \times$ 6.25).

Table 2. Nitrogenous components analysed in the ray muscle

\begin{tabular}{llll}
\hline $\begin{array}{l}\text { Total nitrogen } \\
(\%, \mathrm{n}=3)\end{array}$ & $\begin{array}{l}\text { Protein nitrogen } \\
(\%, \mathrm{n}=3)\end{array}$ & $\begin{array}{l}\text { Non-protein nitrogen } \\
(\%, \mathrm{n}=3)\end{array}$ & $\begin{array}{l}\text { Urea } \\
(\%, \mathrm{n}=3)\end{array}$ \\
\hline 3.34 & 2.43 & 0.98 & 2.02
\end{tabular}

Table 3. Fatty acid composition from ray (Raja radiata)

Fatty acid Composition
(a) (b)

Saturated

$\begin{array}{lll}16: 0 & 5.38 & 0.150 \\ 17: 0 & 0.40 & 0.011 \\ 18: 0 & 2.96 & 0.080 \\ \text { Total saturated } & 8.74 & 0.250\end{array}$

Monoenoic

$\begin{array}{lll}16: 1 n 7 & 2.17 & 0.060 \\ 17: 1 n 7 & 0.43 & 0.012 \\ 18: 1 n 9 & 8.11 & 0.230 \\ 18: 1 n 7 & 2.93 & 0.083 \\ 20: 1 n 9 & 1.44 & 0.040 \\ \text { Total monoenoic } & 15.18 & 0.430\end{array}$




\begin{tabular}{cclc}
\hline Polyenoic & & & \\
& $18: 2 \mathrm{n} 6$ & 0.44 & 0.012 \\
$20: 2 \mathrm{n} 6$ & 0.50 & 0.014 \\
$20: 3 n 6$ & 0.22 & 0.006 \\
$20: 4 \mathrm{n} 6$ & 2.44 & 0.069 \\
$20: 5 n 3$ & 10.78 & 0.310 \\
$22: 6 n 3$ & 4.46 & 0.130 \\
Total polyenoic & 18.84 & 0.540 \\
Total n-3 PUFA & 15.24 & 0.440 \\
Total n-6 PUFA & 3.60 & 0.101 \\
n-3/n-6 & & 4.23 & 4.350 \\
\hline
\end{tabular}

(a) Calculated as percentage of total lipids (\%).

(b) Calculated as percentage of dry weight (\%). 